\title{
Effects of Simulated Microgravity on Functions of Neutrophil-like HL-60 Cells
}

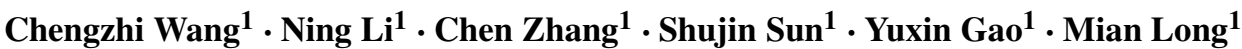

Received: 12 February 2015 / Accepted: 3 November 2015 / Published online: 13 November 2015

(C) Springer Science+Business Media Dordrecht 2015

\begin{abstract}
Altered gravity, especially microgravity affects cellular functions of immune cells and can result in immune dysfunction for long-term, manned spaceflight and space exploration. The underlying mechanism, however, of sensing and responding to the gravity alteration is poorly understood. Here, a rotary cell culture system (RCCS) bioreactor was used to elucidate the effects of simulated microgravity on polymorphonuclear neutrophils (PMN)-like HL-60 cells. Alteration of cell morphology, up-regulation of (nitric oxide) NO production, enhancement of interleukin-6 (IL6), interleukin-8 (IL-8), and monocyte chemotactic protein 1 (MCP-1) secretion, and diversity of cellular adhesion molecule expression were observed for the cells cultured in RCCS, leading to the up-regulated inflammatory immune responses and host defense. It was also indicated that such alterations in biological responses of PMNs mediated the reduced rolling velocity and decreased adhesion of PMNlike HL-60 cells on endothelial cells under shear flow. This work furthers the understandings in the effects and mechanism of microgravity on PMN functions, which are
\end{abstract}

Chengzhi Wang and Ning Li, both authors contributed equally to this work.

Electronic supplementary material The online version of this article (doi:10.1007/s12217-015-9473-6) contains supplementary material, which is available to authorized users.

Mian Long

mlong@imech.ac.cn

1 Key Laboratory of Microgravity (National Microgravity Laboratory), Center of Biomechanics and Bioengineering, and Beijing Key Laboratory of Engineered Construction and Mechanobiology, Institute of Mechanics, Chinese Academy of Sciences, Beijing 100190, China potentially helpful for optimizing the countermeasures to immune suppression in the future long-term, manned spaceflight.

Keywords HL-60 - PMN - Effects of simulated microgravity $\cdot$ RCCS $\cdot$ Flow chamber

\section{Introduction}

Astronaut health is critical in spaceflight since such pathophysiological alterations of astronauts as immune dysfunctions or cardiovascular diseases usually take place during in-flight or post flight. Immune dysfunction under microgravity affects the astronaut health directly and leads to infection, as reported in many spaceflight programs and International Space Station (ISS). Taking Apollo program as an example, over $50 \%$ of the crew members suffered illnesses during space missions, including respiratory infection, gastroenteritis, urinary tract infection, and skin infection (Hawkins and Zieglschmid 1975). Thus, understanding the effects of microgravity on the human immune system is essential to ensure the health, biosafety, and manned performance of astronauts during spaceflights. While scientists have worked intensively on preventing human infections in spaceflight, it is still an unsolved issue since the underlying mechanisms remain unclear in most contents.

Cellular responses under microgravity are crucial to understand the biological and physiological processes in space. PMNs, the predominant circulating phagocytes, are the first to reach the sites of infection and play a major role in producing resistance to bacterial infections (Sawyer et al. 1989), and also important in vascular injury during acute inflammatory responses (Varani and Ward 1994). Unlike other leukocytes which have been investigated extensively 
during spaceflight and under the effects of simulated microgravity (Sun et al. 2008; Long et al. 2009; Feuerecker et al. 2013; Herranz et al. 2013; Long 2014), only quite a few studies have been reported about the effects of microgravity on PMN responses. During spaceflight or post-flight, the amount of PMNs is 1.5- to 1.85 -fold increased to supplement the innate immunity dysfunction (Stowe et al. 1999; Kaur et al. 2004). PMN chemotactic dose is 10 -fold reduced in the optimal dose response after landing and PMN adhesion to endothelial cells is enhanced before and after spaceflight (Stowe et al. 1999). Parabolic flight induces an increase in PMN number and the capability of PMNs to produce hydrogen peroxide $\left(\mathrm{H}_{2} \mathrm{O}_{2}\right)$ in response to soluble stimuli (Kaufmann et al. 2009). These works seemingly indicate that the action of microgravity has enhanced the immune response of PMNs, which is inconsistent with the reduced capability of lymphocytes (Cogoli and Tschopp 1985; Konstantinova et al. 1993; Meshkov and Rykova 1995; Mills et al. 2002; Mills et al. 2008, 2013), monocytes (Kaur et al. 2005, 2008; Crucian et al. 2011), NK cells (Rykova et al. 1992; Konstantinova et al. 1993, 1995; Mehta et al. 2001), and macrophages (Armstrong et al. 1995; Hsieh et al. 2005; Ortega et al. 2012; Adrian et al. 2013; Wang et al. 2014, 2015; Brungs et al. 2015; Paulsen et al. 2015) under microgravity. The underlying mechanisms for such the difference remain unclear.

A rotating wall vessel (RWV) bioreactor (RCCS) developed by NASA, has been proven to be an efficient way to simulate, at least partially, the effects of microgravity on cellular responses with lower cost compared with spaceflight (Goodwin et al. 1993; Baker and Goodwin 1997; Martin et al. 2000; Savary et al. 2001; Singh et al. 2010), even though how to stimulate the space microgravity environment on ground is a complicated issue and remains to be solved (Long 2014; Warnke et al. 2015). RCCS has been widely used for elucidating the effects of microgravity on lymphocytes (Bai et al. 2011), macrophages (Wang et al. 2014, 2015) and endothelial cells (Versari et al. 2007). To date, no data has been reported about PMNs cultured in RCCS, probably because PMNs isolated from whole blood exhibit a relatively short half-life (several hours) (Lefort et al. 2009; Carrigan et al. 2005) thereby precluding longterm culture. Alternatively, human promyelocytic leukemia cell line HL-60 has been widely used as a model for leukocytes to study their functions, since they can be differentiated into monocyte-like, eosinophil-like, or PMN-like cells using distinct inducing agents (Collins et al. 1977; Newburger et al. 1979; Miura et al. 2000; Tsiftsoglou et al. 2003; Carrigan et al. 2005). Here we applied the RCCS bioreactor to unravel the effects of simulated microgravity on both intact HL-60 cells (promyelocytes) and dimethyl sulfoxide (DMSO)-differentiated HL-60 cells (PMN-like cells). Comparing these two types of HL-60 cells, we further attempted to explain whether the effects of simulated microgravity regulates distinctly the different leukocytes and whether the increased number and activity of PMNs after spaceflight is linked to PMN maturation. We also used lipopolysaccharide (LPS), the major component of the outer membrane of Gram-negative bacteria, to assess the ability of PMNs to defense pathogen infection under the effect of simulated microgravity. Cell morphology and functions such as NO production, inflammatory cytokine secretion, cellular adhesion molecule expression, and flow-induced adhesion were found to alter after exposure to the effects of simulated microgravity in this study.

\section{Materials and Methods}

\section{Cell Culture, Differentiation, and Effects of Simulated Microgravity}

Human promyelocytic leukemia HL-60 cells obtained from American Type Culture Collection (Manassas, VA) were cultured in RPMI 1640 medium supplemented with $10 \%$ fetal bovine serum (FBS), $2 \mathrm{mM} \mathrm{L}$-glutamine, 100 units $/ \mathrm{mL}$ penicillin and $100 \mu \mathrm{g} / \mathrm{mL}$ streptomycinin $5 \%$ carbon dioxide $\left(\mathrm{CO}_{2}\right)$ humidified air at $37^{\circ} \mathrm{C}$. The cells were induced to undergo differentiation to granulocytes by incubating them at a concentration of $5 \times 10^{5}$ cells $/ \mathrm{mL}$ in the presence of $1.25 \%$ DMSO for 5 days (Miura et al. 2000; Carrigan et al. 2005). For effects of simulated microgravity, RCCS developed by NASA was used (Savary et al. 2001; Singh et al. 2010). Since RCCS can only simulate microgravity to limited aspects, we keep the conservative term as effects of simulated microgravity. With rotating in a stable speed, medium inside RCCS would suffer very low shear forces and there would be mechanical equilibrium of gravity, shear forces and centrifuge forces. Under the effects of simulated microgravity, most cells cultured in the RCCS have 3-D growth without sedimentation and wouldn't collide to the rotating wall of RCCS. Both HL-60 and DMSO-differentiated HL60 cells were cultured in suspension. They were seeded into a T25 tissue culture flask (standard static control) or disposable RCCS (RCCS-D vessels; Synthecon Inc., Houston, TX) at a concentration of $1 \times 10^{5}$ cells $/ \mathrm{mL}$ in a $10-\mathrm{mL}$ volume of culture medium. $1 \mu \mathrm{g} / \mathrm{mL}$ LPS was added in the medium in order to stimulate the cells in some cases. The RCCS was rotated at $15 \mathrm{rpm}$ for 3 days in the same incubator with the control T25 flask. This rotating speed was chosen according our preliminary experiments which indicates that $15 \mathrm{rpm}$ would be optimal for HL-60 cell growth in RCCS (supplemental Fig. 1). In those preliminary tests, we investigated cell proliferation, cell apoptosis, plate binding, transwell migration and adhesion molecules under different rotating speed, which varied from $5 \mathrm{rpm}$ to $25 \mathrm{rpm}$. 
However, no significant differences appeared in all tests except of significantly increased cell proliferation at $15 \mathrm{rpm}$ compared to other rotating speed. It was notice that the speed of $15 \mathrm{rpm}$ was also chosen in other studies as the rotating speed of RCCS (Yi et al. 2009; Zhang et al. 2010). Each experiment was repeated at least in triplicate.

\section{Cell Morphology and Cytoskeleton Staining}

Cells were harvested from RCCS or T25 flask, washed with phosphate-buffered saline (PBS), and fixed with $4 \%$ paraformaldehyde at room temperature for $15 \mathrm{~min}$. After being washed in PBS, cells were stained with $5 \mu \mathrm{g} / \mathrm{mL}$ FITC-conjugated phalloidin for cytochemical labeling for filamentous actin (F-actin). Cells were incubated at $37^{\circ} \mathrm{C}$ for $60 \mathrm{~min}$, rinsed with PBS twice, and re-suspended with a drop of ProLong Gold anti-fade reagent with DAPI (Life Technologies, Grand Island, NY). The cell suspension was then added onto glass slide and covered with coverslip. After curing for $24 \mathrm{~h}$ at room temperature in the dark, the images of stained cells were examined using a confocal laser-scanning microscope (Zeiss LSM710, Germany) with a $63 \times$ oil-immersion objective. Cell morphology was determined using Image $\mathbf{J}$ software, including its projected area and circularity (denoted as the $(4 \times \pi \times$ area $) /$ perimeter $\left.^{2}\right)$.

\section{Cell Apoptosis Analysis}

Cell apoptosis analysis was performed using the Annexin V-PE apoptosis detection kit I (BD Biosciences, San Jose, CA) according to the manufacturer's instructions. About $1 \times 10^{4}$ cells were measured for each experiment via a FACSCanto II flow cytometer (BD Biosciences) and analyzed with manufacturer-provided FACSDiva software. The Annexin V and 7-Amino-Actinomycin (7-AAD) negative cells were defined as intact healthy cells, whereas Annexin $\mathrm{V}$ positive and 7-AAD negative or both Annexin V and 7AAD positive cells were taken as a measure of early or late apoptosis, respectively.

\section{Cell Cycle Analysis}

Cell cycle analysis was assessed using FACSCanto II flow cytometer following the nuclei stained by a CycleTEST PLUS DNA Reagent Kit (BD Biosciences). Cell cycle distribution was obtained using FACSDiva software.

\section{NO Production Analysis}

Harvested $5 \times 10^{5}$ cells were incubated in $0.5 \mu \mathrm{M} 4$ 4-Amino5-methylamino- $2^{\prime}, 7^{\prime}$-difluorofluorescein diacetate (DAFFM DA, Sigma-Aldrich, St. Louis, MO) for $30 \mathrm{~min}$ at $37^{\circ} \mathrm{C}$.
Washed cells were analyzed for intracellular NO production using FACSCanto II flow cytometer.

\section{Reactive Oxygen Species (ROS) Production Analysis}

Another aliquot of harvested $5 \times 10^{5}$ cells were treated with CellROX Green Reagent (Life Technologies) at a final concentration of $0.5 \mu \mathrm{M}$ for $30 \mathrm{~min}$ at $37^{\circ} \mathrm{C}$, and then washed with PBS. The intracellular ROS level was measured by FACSCanto II flow cytometer.

\section{Phagocytosis of Latex Beads}

The phagocytosis activity of the harvested cells was assessed based on the uptake of bacterial-sized 2- $\mu \mathrm{m}$ fluorescent latex beads (Sigma). $5 \times 10^{5}$ cells were mixed with $1 \times 10^{7}$ fluorescent latex beads in $0.5 \mathrm{~mL}$ PBS. The mixture was incubated at $37^{\circ} \mathrm{C}$ for $30 \mathrm{~min}$ without shaking for $1 \mathrm{~h}$. Then cells were washed with $1 \mathrm{~mL}$ PBS and spun down at $100 \times \mathrm{g}$ for $2 \mathrm{~min}$ for three times to remove un-phagocytosed beads. The cells were then analyzed by FACSCanto II flow cytometer to determine the phagocytosis rate (denoted as the ratio of phagocytosed beads to total cells).

\section{Cytokine Secretion Analysis}

Culture supernatant was harvested from RCCS or control flask and used for enzyme-linked immunosorbent assay (ELISA). All supernatant samples were stored at $-70^{\circ} \mathrm{C}$ until test. Interleukin-1 (IL-1 $\beta$ ), IL-6, IL-8, macrophage inflammatory protein- 1 alpha (MIP- $1 \alpha$ ) and MCP-1 levels in culture supernatant were measured with ELISA kits (R\&D Systems, Minneapolis, MN) by following the manufacturer's protocol. Cytokine concentration was determined from a standard curve prepared from the provided controls. The sensitivities of the ELISA kits were as follows: IL- $1 \beta, 0.057 \mathrm{pg} / \mathrm{mL}$; IL-6, 0.039 $\mathrm{pg} / \mathrm{mL} ; \mathrm{IL}-8,0.28 \mathrm{pg} / \mathrm{mL}$; MIP- $1 \alpha, 10 \mathrm{pg} / \mathrm{mL}$; and MCP-1, $1.7 \mathrm{pg} / \mathrm{mL}$.

\section{Expression of Cellular Adhesion Molecules}

Phycoerythrin (PE)-conjugated mouse IgG1 monoclonal antibodies (mAbs) against $\alpha_{\mathrm{L}}$ integrin (CD11a, clone HI111), $\alpha_{\mathrm{M}}$ integrin (CD11b, clone ICRF44), $\beta_{1}$ integrin (CD29, clone TS2/16), P-selectin glycoprotein ligand 1 (PSGL-1, CD162, clone KPL-1), and isotype-matched irrelevant mouse IgG1 (clone MOPC-21) were purchased from Biolegend (San Diego, CA). Five aliquots of cells harvested from RCCS or T25 flask were respectively incubated with the respective mAbs at a concentration of $10 \mu \mathrm{g} / \mathrm{mL}$ for $30 \mathrm{~min}$ on ice. Following washing, fluorescent cells were analyzed by FACSCanto II flow cytometer. Analysis was 
done by gating on the cell population, and the geometric mean fluorescence intensity (GMFI) of the cells was used to present the expression of the four adhesion molecules. The GMFI of isotype-mediated binding was subtracted from the total binding.

\section{Flow Chamber Assay}

HL-60 cell rolling and adhesion on umbilical vein endothelial cell (HUVEC, ATCC) monolayer under shear flow were measured using a circular GlycoTech flow cell system (for a $35 \mathrm{~mm}$ tissue culture dish, \#31-001, Gaithersburg, Maryland), respectively. HUVECs were cultured in a $35-\mathrm{mm}$ tissue culture dish, stimulated with $100 \mathrm{ng} / \mathrm{ml}$ TNF- $\alpha$ (R\&D Systems) for $12 \mathrm{~h}$ and assembled onto the flow chamber with $2 \mathrm{~cm}$ length $\times 0.5 \mathrm{~cm}$ width $\times 0.01$ inch height. For rolling velocity test, intact or DMSO-differentiated HL60 cells were cultured in T-25 flask or RCCS bioreactor with $1 \mu \mathrm{g} / \mathrm{ml}$ LPS for 3 days, re-suspended in Hank's balanced salt solution (HBSS, with $\mathrm{Ca}^{2+}$ and $\mathrm{Mg}^{2+}$ ) containing $1 \% \mathrm{BSA}$ at a concentration of $5 \times 10^{5}$ cells $/ \mathrm{mL}$, and perfused into the flow chamber at 1 dyne $/ \mathrm{cm}^{2}$ for 30 min. For shear-resistance test, the harvested cells were re- suspended in the same buffer at a concentration of $2 \times 10^{6}$ cells $/ \mathrm{mL}$, perfused into the flow chamber at 0.1 dyne $/ \mathrm{cm}^{2}$ for $10 \mathrm{~min}$, and incubated for $10 \mathrm{~min}$ without flow in order to allow cell adhesion to occur. After washing out non-adherent HL-60 cells at $0.1 \mathrm{dyne} / \mathrm{cm}^{2}$, the shear stress increased stepwise from $1,2,4,8,16$ to 32 dyne $/ \mathrm{cm}^{2}$ for $30 \mathrm{~s}$ each stress. The dynamic processes of both the rolling and shear-resistance tests were recorded at $10 \times / \mathrm{NA} 0.25$ objective using a CCD camera. The rolling velocity and adherent cell numbers at each stress were analyzed from the video using NIS-ELEMENT software (Nikon, Tokyo, Japan).

\section{Statistical Analysis}

Data were expressed as mean \pm SEM of at least three independent experiments. All data were tested for their deviations from the Gaussian distribution using the KolmogorovSmirnov test. Unpaired two-tail Student's t-test and MannWhitney test (depending on the results of the normality test) were used to assess the statistical significance of the differences. Values of $p<0.05$ were considered statistically significant.
Fig. 1 DMSO treated HL-60 differentiation. (a-b) Confocal images of intact (a) and DMSO-differentiated (b) HL-60 cells. F-actin was labeled by FITC-conjugated phalloidin (green) while the nucleus was stained with DAPI (blue). (c-d) Mac-1 expression on intact (c) and DMSO-differentiated (d) HL-60 cells a
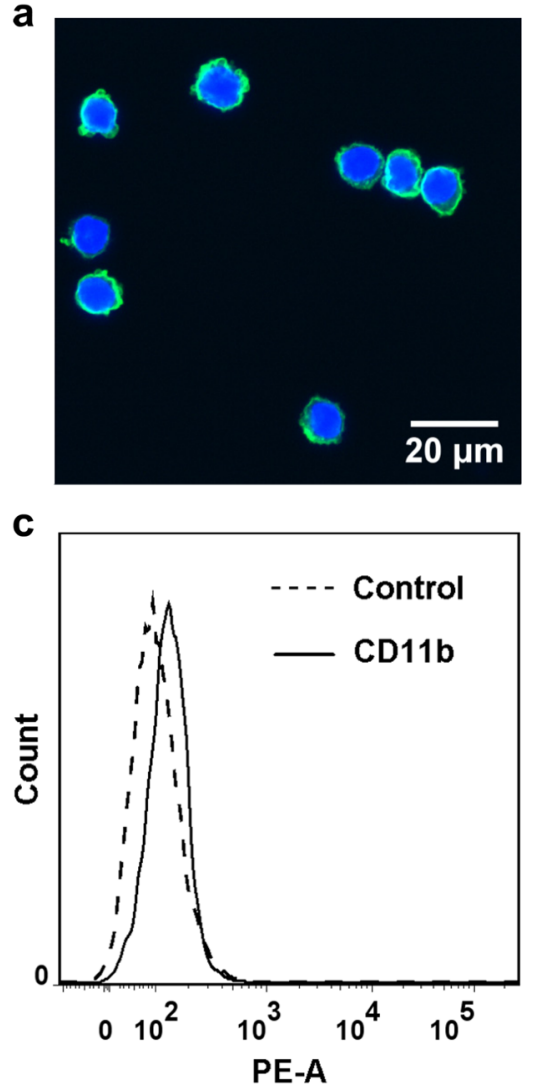

b

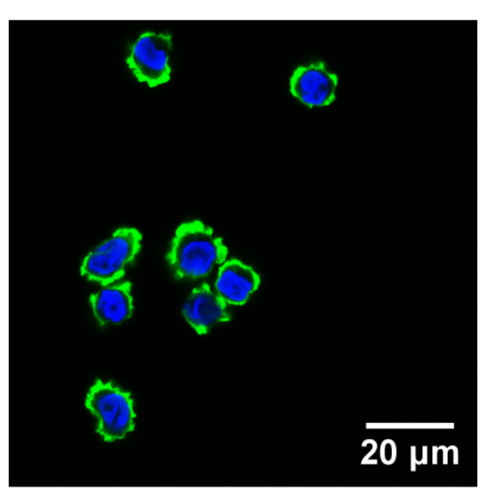

d

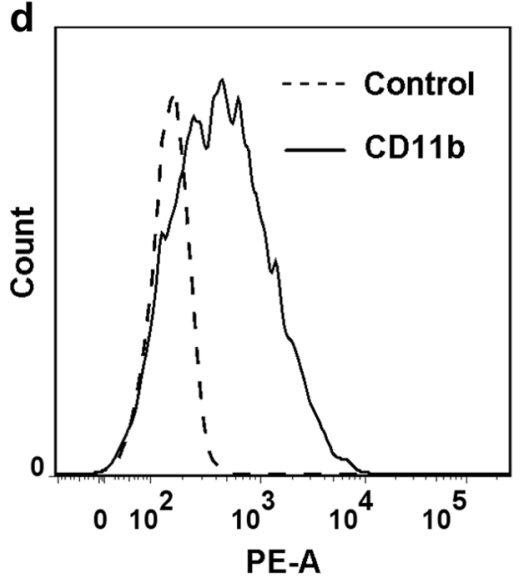




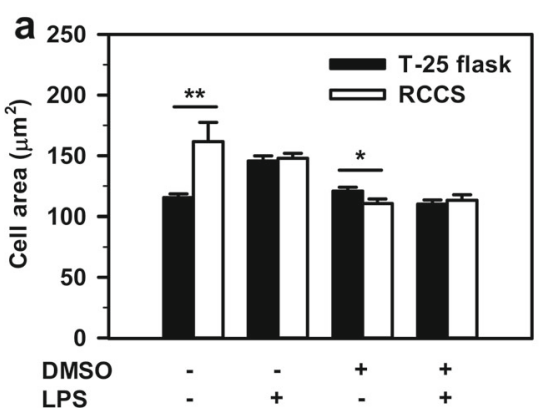

Fig. 2 Cell projected area (a) and circularity (b) of intact and DMSOdifferentiated HL-60 cells cultured in T-25 flasks (closed bars) or in the RCCS bioreactor (open bars) with or without LPS stimulation.

\section{Results}

\section{Differentiation of PMN-like HL-60 Cells}

The DMSO-differentiated HL-60 cells showed the alterations of cell morphology and actin cytoskeleton (Fig. 1ab). It was indicated that, after DMSO treatment, the cells tend to present multiple nuclei, to form peripheral

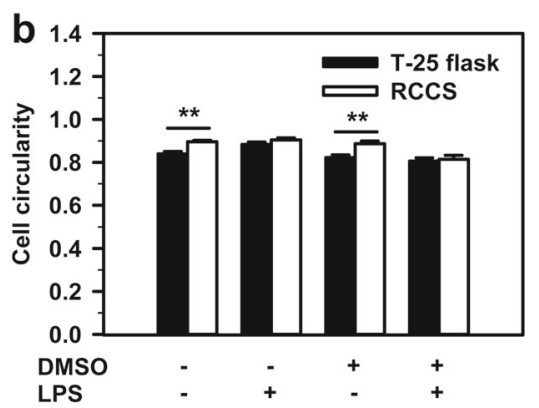

Data are presented as mean \pm SEM of total $50-100$ cells in each case. ${ }^{*}, p<0.05 ;^{* *}, p<0.01$, indicating statistically significant difference between the cells in flask and in RCCS

pseudopodia, and to yield high F-actin expression colocalized with those pseudopodia, which demonstrate the phenotypes of PMN-like cells. As a marker of PMN-like differentiation, undifferentiated HL-60 cells presented essentially no macrophage- 1 antigens (Mac1, integrin $\left.\alpha_{\mathrm{M}} \beta_{2}, \mathrm{CD} 11 \mathrm{~b} / \mathrm{CD} 18\right)$ while DMSO treated HL-60 cells expressed a widely distributed Mac-1 (Fig. 1c-d). a

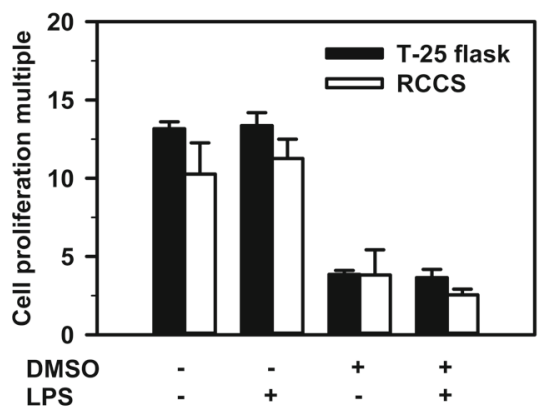

d

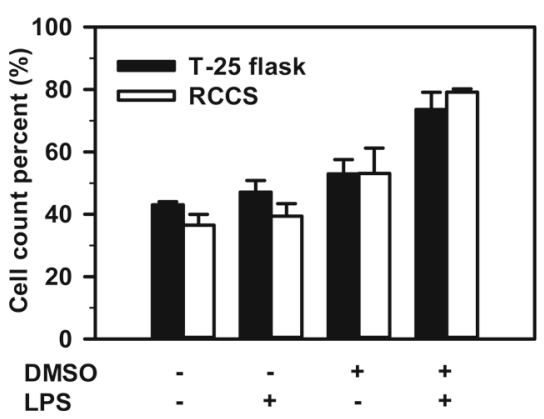

Fig. 3 Cell proliferation (a), apoptosis (b-c), and cell cycle (d-f) of intact and DMSO-differentiated HL-60 cells cultured in flasks (closed bars) or in the RCCS (open bars) with or without LPS stimulation. (a) Cell proliferation folds after $72 \mathrm{~h}$ culture. (b-c) Annexin V flow

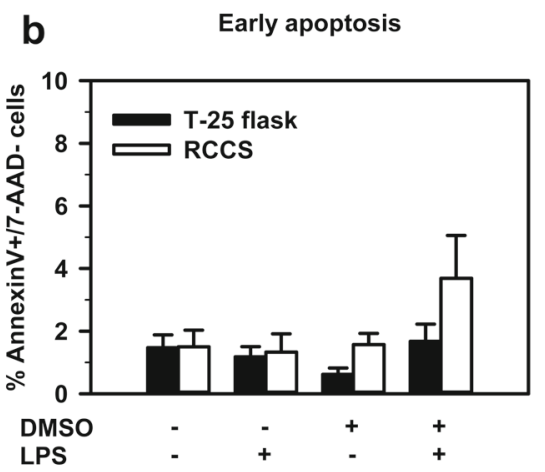

C Late apoptosis or dead

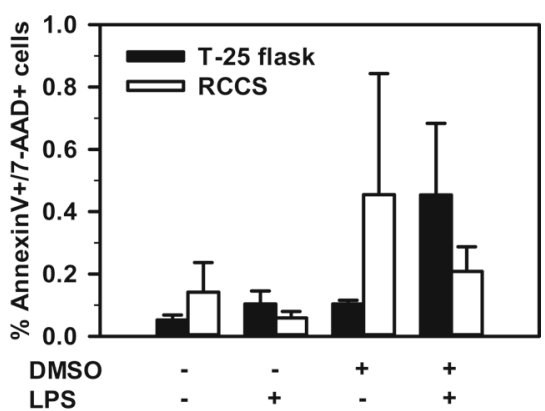

f

Cell cycle_G ${ }_{2}$

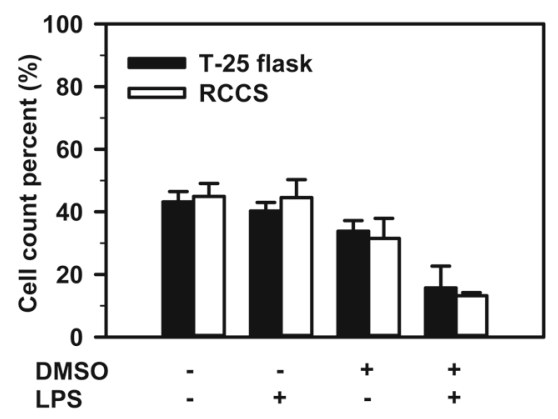

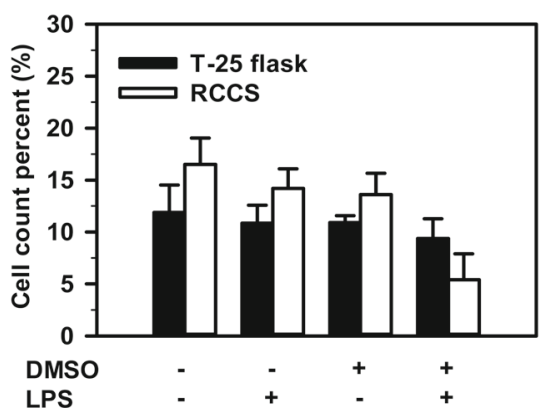

cytometry analysis for early (b) or late (c) apoptosis, respectively. (df) Cell cycle analysis of $\mathrm{G}_{0} / \mathrm{G}_{1}(\mathrm{~d}), \mathrm{S}(\mathbf{e})$, and $\mathrm{G}_{2}$ (f) phases. Data are presented as mean \pm SEM in triplet 


\section{Effects of Simulated Microgravity on Cell Morphology and Cytoskeleton}

We examined the morphological changes of intact and DMSO-differentiated HL-60 cells under the effects of simulated microgravity, which are in the presence or absence of LPS stimulation (Fig. 2). In the absence of LPS stimulation, cell project area was 1.4-fold increased in RCCS for the intact HL-60 cells, and 0.9-fold decreased for DMSOdifferentiated HL-60 (Fig. 2a). Cell circularity was 1.1-fold enhanced for both the intact and the DMSO-differentiated cells in RCCS (Fig. 2b). After being treated with LPS, no significant difference in cell project area or cell circularity was found between the cells cultured in flask and in RCCS (Fig. 2). We also investigated the changes of cytoskeleton under the effects of simulated microgravity. F-actin proteins were always polymerized around the cell membrane, and no significant difference was found between the suspending HL-60 cells cultured in flask and in RCCS in our experimental settings (data not shown).

\section{Effects of Simulated Microgravity on Cell Proliferation, Apoptosis and Cell Cycle}

Furthermore, we analyzed the proliferation, apoptosis and cell cycle of the HL-60 cells in different conditions (Fig. 3). No significant differences were found in cell proliferation between the cells in flask and in RCCS even though the proliferation multiple is slightly lower for cells in RCCS (Fig. 3a). Similar ratios of early and late apoptosis were also observed for both types of cells, in which the apoptosis rate for DMSO-differentiated cells seemed to present the wide variation with large standard errors in the presence or absence of LPS-stimulation (Fig. 3b-c). For cell cycle, the percentages of three phases for both types of cells were comparable in the distinct stimulations even though the $\mathrm{G}_{2}$-phase percentage is slightly higher for the cells in RCCS than those in flask (Fig. 3d-f). Thus, cell proliferation, apoptosis, and cycle were indifferent between the cells in flask and in RCCS.

\section{Effects of Simulated Microgravity on NO/ROS Production and Phagocytosis}

We further tested the NO/ROS production and phagocytosis ability of HL-60 cells in order to elucidate the effects of simulated microgravity on host defense against bacterial pathogens (Fig. 4). As compared with those in flask, NO production for intact HL-60 cells in RCCS was $0.6 \sim 0.7$ fold decreased in the absence $(p<0.01)$ or presence ( $p=0.08)$ of LPS-stimulation but it was $1.4 \sim 1.8$-fold increased for DMSO-differentiated HL-60 cells in RCCS in the absence ( $p=0.07)$ or presence $(p=0.05)$ of LPSstimulation (Fig. 4a), demonstrating a modest effects of simulated microgravity on NO production and a reverse impact between intact and DMSO-differentiated HL-60 cells. By contrast, no impact on ROS production (Fig. 4b) or phagocytosis (Fig. 4c) was found between the cells in flask and in RCCS.

\section{Effects of Simulated Microgravity on Cytokine Secretion}

To assess if exposure of HL-60 cells to the effects of simulated microgravity has a significant impact on cytokine secretion, we used ELISA assay to profile the secretion of IL- $1 \beta$, IL-6, IL-8, MIP- $1 \alpha$ and MCP- 1 using the supernatants collected from culturing HL-60 cells in RCCS (Fig. 5). Cytokine concentration of culture supernatant remained a low level without LPS stimulation (Fig. 5ae). Specifically, a 3.6-fold increased IL-8 secretion was observed for both intact and DMSO-differentiated HL-60 cells and a 2.6-fold MCP-1 secretion was enhanced for intact HL-60 cells when they are cultured in RCCS (Fig. 5c, e). By contrast, levels of cytokine secretion were increased dramatically in the presence of LPS stimulation through Toll-like receptor (TLR) pathway. Here IL-1 $\beta$, IL-8, and MCP-1 secretions were enhanced 2.6-, 3.9- and 2.3-fold, respectively, in the supernatants of intact HL-60 cells in RCCS compared with those in flask (Fig. 5a, c, e). Moreover, a 1.7-, 3.7- and 1.7-fold increased IL-6, IL-8, and
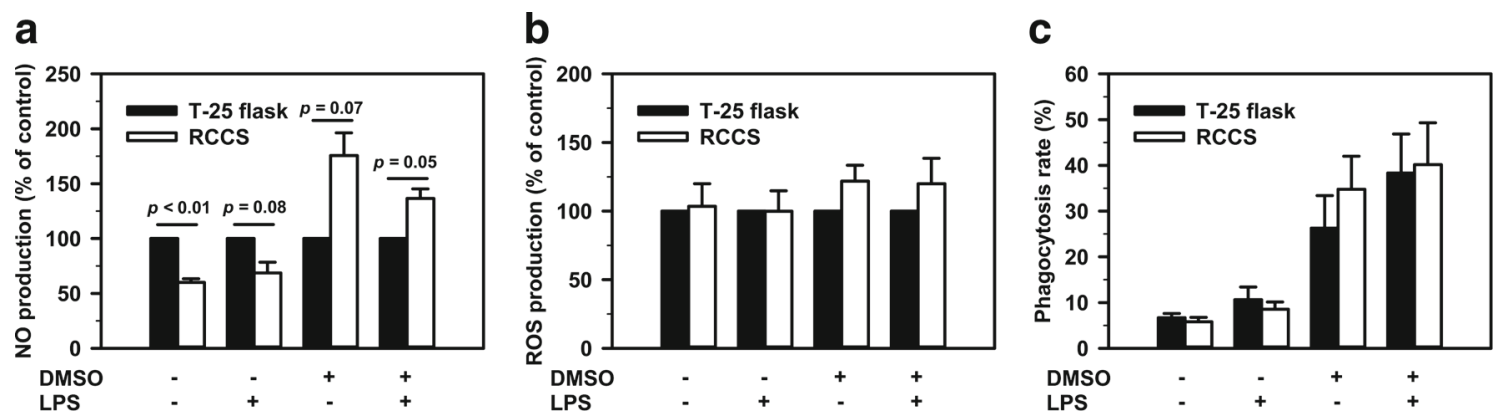

Fig. 4 Intracellular NO (a) and ROS (b) production, and phagocytosis activity (c) of intact and DMSO-differentiated HL-60 cells cultured in flasks (closed bars) or in the RCCS (open bars) with or without LPS stimulation. Data are presented as mean \pm SEM in triplet 

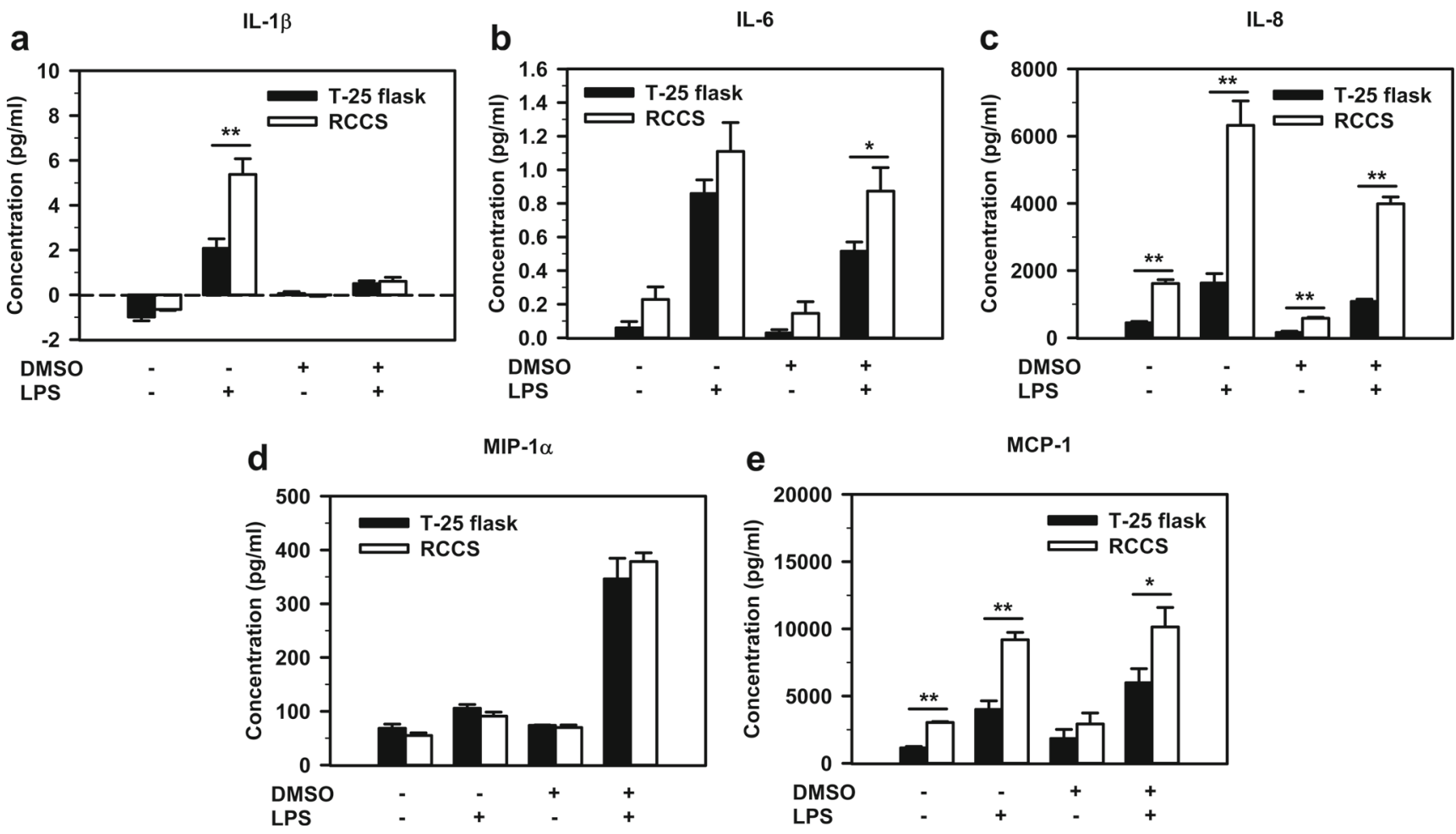

Fig. 5 IL-1 $\beta$ (a), IL-6 (b), IL-8 (c), MIP- $1 \alpha$ (d), and MCP-1 (e) levels in culture supernatant of intact and DMSO-differentiated HL-60 cells cultured in flasks (closed bars) or in the RCCS (open bars) with or without LPS stimulation measured with ELISA kits in biological

triplicate and technical duplicate. Data are presented as mean \pm SEM. ${ }^{*}, p<0.05 ;{ }^{* *}, p<0.01$, indicating statistically significant difference between the cells in flask and in RCCS

MCP-1 secretion were observed for DMSO-differentiated HL-60 cells in RCCS (Fig. 5b-c, e). No significant change was found in the concentration of MIP- $1 \alpha$ in different conditions (Fig. 5d) and the negative values of IL-1 $\beta$ for intact cells with or without LPS stimulation was attributed to the lower values compared with the ELISA nonspecific control binding.

\section{Effects of Simulated Microgravity on the Expression of Adhesion Molecules}

Adhesion molecules such as integrins and selectins play critical roles for the immune system in leukocyte trafficking and migration, immunological synapse formation, costimulation, and phagocytosis (Ley et al. 2007). To investigate if the effects of simulated microgravity has a significant impact on adhesion molecule expression of HL-60 cells, we used flow cytometry to determine the presence of lymphocyte function-associated antigen-1 (LFA-1, integrin $\alpha_{\mathrm{L}} \beta_{2}$, CD11a/CD18, Fig. 6a), Mac-1 (Fig. 6b), very late antigen 4 (VLA-4, integrin $\alpha_{4} \beta_{1}$, CD49d/CD29, Fig. 6c), and PSGL-1 (Fig. 6d) at the cell surface respectively. We found a 1.6- or 1.7-fold LFA-1 up-regulation on intact HL-60 cells cultured

with or without LPS in RCCS compared with those in flask (Fig. 6a). For DMSO-treated HL-60 cells, Mac-1 expression was 3.5- or 2.2-fold enhanced for the cells cultured with $(p<0.05)$ or without $(p=0.08)$ LPS in RCCS. No impacts on VLA-4 expression were found for both types of the cells in the absence or presence of LPS stimulation (Fig. 6c). PSGL-1 expression seemed to be reduced in all the cases at a different content, as exemplified the remarkable decrease for intact cells with LPS stimulation (Fig. 6d).

\section{Effects of Simulated Microgravity on HL-60-Endothelial Interaction}

Finally, we investigated the rolling and adhesion of HL60 cells on HUVEC monolayer under shear flow in order to assess if the effects of simulated microgravity regulates significantly HL-60 cell-endothelial cell interactions. Here intact or DMSO-differentiated HL-60 cells were preincubated by LPS in T25 flask or RCCS while HUVECs were pre-stimulated with TNF- $\alpha$, prior to integrate them into a flow chamber assay. For HL-60 rolling velocity, no significant differences were found for intact HL-60 
Fig. 6 Expression of cellular adhesion molecules LFA-1 (a), Mac-1 (b), VLA-4 (c), and PSGL-1 (d) of intact and DMSO-differentiated HL-60 cells cultured in flasks (closed bars) or in the RCCS (open bars) with or without LPS stimulation by flow cytometry analysis.

Negative values in some cases derived from the non-positive statistics between total and isotype-matched control binding. Data are presented as mean \pm SEM of $3 \sim 6$ independent experiments. ${ }^{*}, p<0.05$; $^{* *}$, $p<0.01$, indicating statistically significant difference between the cells in flask and in RCCS a

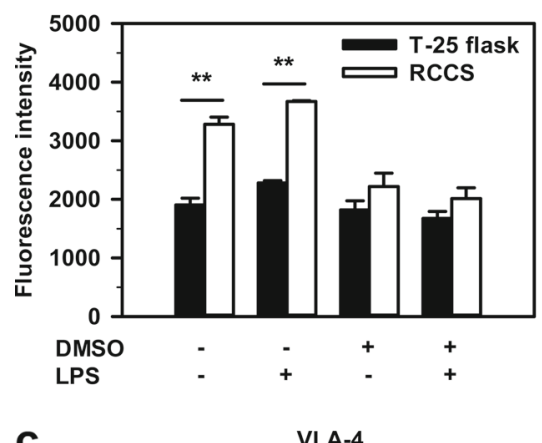

C

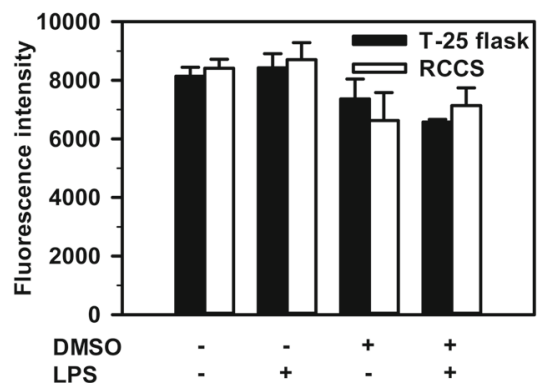

b

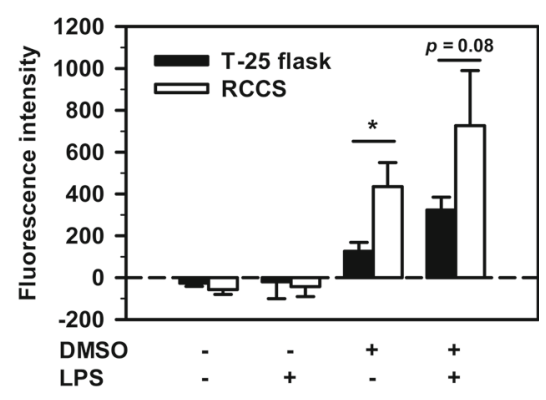

d

PSGL-1

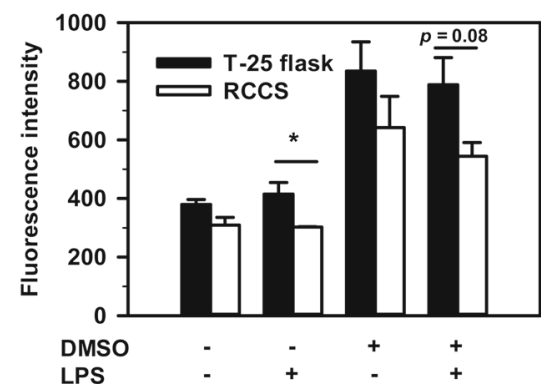

cells after flask or RCCS exposure. After pre-incubation with DMSO, differentiated HL-60 cells yielded a 0.8-fold reduced rolling velocity in RCCS (Fig. 7a), which is consistent with the reduced expression of PSGL-1 and enhanced expression of Mac-1 (cf. Fig. 6b, d). For HL-60 shearresistant adhesion, it was indicated that under a low shear stress (1 2 dyne/cm ${ }^{2}$ ), more intact HL-60 cells remained adhered in RCCS (Fig. 7b), presumably due to the enhanced expression of LFA-1 ( $c f$. Fig. 6a). Such difference was eliminated when applying high shear stress. By contrast, the 0.7-fold decreased adhesion of DMSO-differentiated HL-60 cells was observed in RCCS at $8 \mathrm{dyne} / \mathrm{cm}^{2}$ and no adhesion differences were found between the cells in flask and in RCCS at other given shear stress (Fig. 7c).

\section{Discussion}

In this study, we demonstrated the effects of simulated microgravity on the innate immune responses of HL-60 cells. Such stimulation plays distinct roles on the intact and DMSO-differentiated HL-60 cell. It has a reverse impact on cell project area (Fig. 2a) and NO production (Fig. 4a), and affects different production or expression of cytokines (Fig. 5) and adhesion molecules (Fig. 6). These results provide an insight how altered gravity regulates the functions of neutrophils and the underlying mechanisms which mediate the innate immune responses for long-term, manned spaceflight.
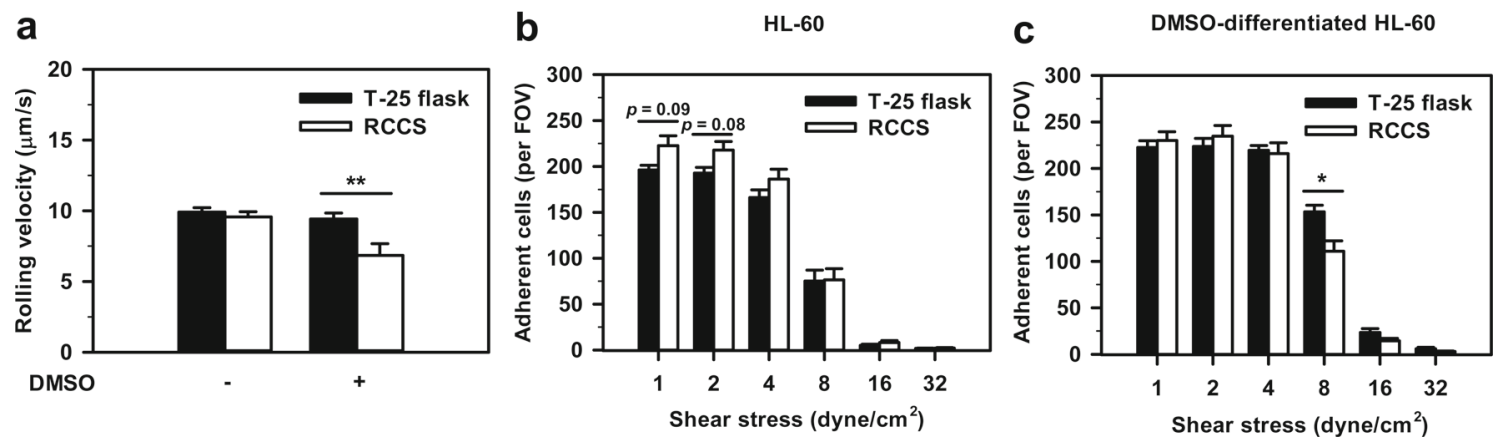

Fig. 7 Shear-induced rolling and adhesions of HL-60 cells on HUVECs. (a) Rolling velocities of intact and DMSO-differentiated HL-60 cells cultured in flasks (closed bars) or in the RCCS (open bars) with LPS stimulation rolling on HUVECs pre-stimulated by TNF- $\alpha$. (b-c) Number of adherent intact (b) and DMSO-differentiated (c) HL-60 cells cultured in flasks (closed bars) or in the RCCS (open bars) per field of view (FOV) under stepwise shear stress of $\tau=1,2,4,8,16$, and $32 \mathrm{dyne} / \mathrm{cm}^{2}$ for $30 \mathrm{~s}$ each. Data are presented as mean \pm SEM. ${ }^{*}, p<0.05$; ${ }^{* *}, p<0.01$, indicating statistically significant difference between the cells in flask and in RCCS 
Table 1 Summaries of effects of simulated microgravity on immune cells and endothelial cells

\begin{tabular}{|c|c|c|c|c|c|c|}
\hline Cell Type & Methods & Cytokine & Adhesion molecules & NO & Oxidative burst & Reference \\
\hline Neutrophils & $\begin{array}{l}\text { Parabolic flight } \\
\text { Spaceflight } \\
\text { HDTBR }\end{array}$ & $\begin{array}{l}\mathrm{IL}-8 \uparrow \\
\mathrm{G}-\mathrm{CSF} \uparrow\end{array}$ & $\begin{array}{l}\text { LFA- } 1 \uparrow \\
\text { Mac- } 1 \downarrow \text { or } \uparrow \\
\text { L-selectin } \downarrow \text { or } \uparrow \\
\text { ICAM- } 1 \downarrow\end{array}$ & & $\begin{array}{l}\mathrm{H}_{2} \mathrm{O}_{2} \text { - or } \uparrow \\
\text { Oxidative burst } \\
\text { capacity - or } \uparrow\end{array}$ & $\begin{array}{l}\text { Stowe et al. 1999; } \\
\text { Kaur et al. 2004; } \\
\text { Kaufmann et al. 2009; } \\
\text { Ortega et al. 2009; } \\
\text { Kaufmann et al. 2011; } \\
\text { Feuerecker et al. 2013; }\end{array}$ \\
\hline HL-60 & RWV & $\begin{array}{l}\text { IL-1 } \beta \uparrow \\
\text { IL-6 - } \\
\text { IL-8 } \uparrow \\
\text { MIP-1 } \alpha- \\
\text { MCP-1 } \uparrow\end{array}$ & $\begin{array}{l}\text { LFA-1 } \uparrow \\
\text { VLA-4 - } \\
\text { PSGL- } 1 \downarrow\end{array}$ & $\mathrm{NO} \downarrow$ & ROS - & Current study \\
\hline $\begin{array}{l}\text { DMSO- } \\
\text { differentiated HL-60 }\end{array}$ & RWV & $\begin{array}{l}\text { IL- } 1 \beta- \\
\text { IL-6 } \uparrow \\
\text { IL- } 8 \uparrow \\
\text { MIP- } 1 \alpha- \\
\text { MCP- } 1 \uparrow\end{array}$ & $\begin{array}{l}\text { LFA-1 - } \\
\text { Mac-1 } \uparrow \\
\text { VLA-4 - } \\
\text { PSGL-1 } \downarrow\end{array}$ & $\mathrm{NO} \uparrow$ & ROS - & Current study \\
\hline Monocytes & Spaceflight & $\begin{array}{l}\text { IL- } 6 \downarrow \\
\text { TNF- } \alpha \downarrow \\
\text { IL- } 10 \downarrow \\
\text { IL- } 1 \beta \uparrow \text { or } \downarrow \\
\text { IL- } 8 \uparrow \text { or } \downarrow\end{array}$ & $\begin{array}{l}\text { LFA-1 } \downarrow \\
\text { L-selectin } \downarrow\end{array}$ & & & $\begin{array}{l}\text { Mills et al. 2002; } \\
\text { Kaur et al. 2008; } \\
\text { Crucian et al. 2011; }\end{array}$ \\
\hline Macrophages & $\begin{array}{l}\text { RWV } \\
\text { Clinostat } \\
\text { Parabolic flight } \\
\text { Spaceflight }\end{array}$ & $\begin{array}{l}\text { IL-6 } \uparrow \text { or } \downarrow \\
\text { IL-12B } \downarrow \\
\text { TNF- } \alpha \downarrow \\
\text { IL- } 1 \beta-\end{array}$ & $\begin{array}{l}\text { ICAM-1 } \uparrow \\
\text { Mac- } 1 \downarrow \\
\text { PECAM-1 } \uparrow \\
\text { CD44 - }\end{array}$ & $\mathrm{NO} \downarrow$ & $\operatorname{ROS} \downarrow$ & $\begin{array}{l}\text { Armstrong et al. 1995; } \\
\text { Hsieh et al. 2005; } \\
\text { Adrian et al. 2013; } \\
\text { Wang et al. 2014; } \\
\text { Brungs et al. 2015; } \\
\text { Paulsen et al. 2015; } \\
\text { Wang et al. 2015; }\end{array}$ \\
\hline T lymphocytes & $\begin{array}{l}\text { RWV; } \\
\text { Spaceflight }\end{array}$ & $\begin{array}{l}\text { IFN- } \gamma \downarrow \text { or } \uparrow \\
\text { IL- } 4 \downarrow \\
\text { IL-6 } \uparrow \\
\text { TGF- } \beta \uparrow \\
\text { IL-17 } \uparrow \\
\text { IL- } 2 \downarrow \\
\text { IL- } 1 \beta \uparrow \\
\text { IL-10 } \uparrow \\
\text { MIP- } 1 \alpha \uparrow\end{array}$ & $\begin{array}{l}\text { L-selectin - } \\
\text { LFA-1 } \downarrow \\
\text { ICAM-1 } \downarrow\end{array}$ & & & $\begin{array}{l}\text { Cooper and Pellis } 1998 ; \\
\text { Mills et al. 2002; } \\
\text { Bai et al. 2011; } \\
\text { Gridley et al. 2013; }\end{array}$ \\
\hline Endothelial cells & $\begin{array}{l}\text { RPM } \\
\text { RWV }\end{array}$ & $\begin{array}{l}\text { IL- } 6 \downarrow \text { or } \uparrow \\
\text { TNF- } \alpha \downarrow \\
\text { IL- } 1 \alpha \downarrow \\
\text { IL- } 8 \downarrow \text { or } \uparrow \\
\text { bFGF } \downarrow\end{array}$ & $\begin{array}{l}\text { ICAM-1 } \downarrow \\
\text { E-selectin } \downarrow \\
\text { VCAM-1 } \downarrow\end{array}$ & $\begin{array}{l}\text { eNOS } \uparrow \\
\mathrm{NO} \uparrow\end{array}$ & & $\begin{array}{l}\text { Versari et al. 2007; } \\
\text { Ulbrich et al. 2008; } \\
\text { Griffoni et al. 2011; } \\
\text { Grenon et al. 2013; }\end{array}$ \\
\hline
\end{tabular}

HDTBR, head-down-tilt bed rest; RWV, rotating wall vessel (i.e., RCCS used in the current work); RPM, random positioning machine

IL, interleukin; G-CSF, granulocyte-macrophage colony-stimulating factor; MIP- $1 \alpha$, macrophage inflammatory protein- $1 \alpha$; MCP-1, monocyte chemotactic protein 1 ; TNF- $\alpha$, tumour necrosis factor- $\alpha$; IFN- $\gamma$, Interferon- $\gamma$; TGF- $\beta$, transforming growth factor- $\beta$; bFGF, basic fibroblast growth factor

LFA-1, lymphocyte function-associated antigen-1; Mac-1, macrophage-1 antigen; ICAM-1, VLA-4, very late antigen 4; PSGL-1, P-selectin glycoprotein ligand 1; ICAM-1, intercellular cell adhesion molecule-1; PECAM-1, platelet/endothelial cell adhesion molecule 1; VCAM-1, vascular cell adhesion molecule 1

NO, nitric oxide; eNOS, endothelial nitric oxide synthase

$\mathrm{H}_{2} \mathrm{O}_{2}$, hydrogen peroxide; ROS, reactive oxygen species

Legend: $\uparrow$, increased; $\downarrow$, decreased; -, unchanged 
The cytoskeletal proteins have been proposed as potential gravity sensor, and significant changes of cytoskeletal network have been observed under microgravity environment both during spaceflight and in ground-based simulation techniques (Vorselen et al. 2014). Although we have not seen obvious disorganization of the F-actin under the effects of simulated microgravity, the cell shape changes of HL-60 cells (Fig. 2) could be considered as a sign for cytoskeletal change. It is rather remarkable that most changes happen in non-LPS group, but not in LPS group. Since LPS could also induce actin polymerization and localization in PMNs (Zemans and Arndt 2009), it might induce a potential compensation to the effects of simulated microgravity.

The amount of PMNs is increased during spaceflight or post-flight (Stowe et al. 1999; Kaur et al. 2004), probably due to the enhanced PMN maturation and release from the bone marrow or the decreased PMN apoptosis. Comparing the responses of intact and DMSO-differentiated HL-60 cells under the effects of simulated microgravity, no clear evidence is found for PMN maturation between them (Figs. 2-7). The apoptosis rate remains unchanged under RCCS exposure compared to $1 \mathrm{~g}$ (Fig. 3b, c), which is also inconsistent with the hypothesis. Increased IL-8 secretion is observed in all cases (Fig. 5c), which could be the reason of PMN increase after spaceflight, since IL- 8 might induce more PMNs released from the bone marrow (Loos et al. 2009; Van Eeden and Terashima 2000).

Impaired immune responses under microgravity have been reported for other types of leukocytes such as $T$ lymphocytes, monocytes, macrophages as well as endothelial cells. Interestingly, an enhanced immune response is reported for PMNs under microgravity, as seen in our work and those clues from literatures. Table 1 summarize our data and further compare this work with published findings, as below.

NO is one of the important messengers and effector molecules, which have close relationship with immune function and can nonspecifically inhibit or kill bacteria, fungi, viruses, and parasites (Chen et al. 2014). In addition to the direct toxicity, NO could also influence many physiological processes from DNA transcription and replication to protein synthesis and secretion (Pavanelli et al. 2010). NO production is demonstrated to be involved in mechanotransduction of mechanically stimulated bone cells (McGarry et al. 2008) and endothelial cells (Rizzo et al. 1998), and regulated by the effects of simulated microgravity (Random Positioning Machine) in endothelial cells (Grenon et al. 2013) and macrophages (Hsieh et al. 2005). NO is synthesized by a class of NADPH-dependent NO synthases (NOSs) and regulated by arginase (Shatanawi et al. 2015). NO production is significantly increased by up-regulating endothelial NOS (eNOS) in endothelial cells under the effects of simulated microgravity (Grenon et al. 2013), and decreased due to the enhanced arginase I expression in macrophages (Wang et al. 2015). Here we observe that NO production is decreased for intact HL-60 cells but slightly increased for DMSO-differentiated HL-60 cells under the effects of simulated microgravity (Fig. 4a). This reverse impact might be a result of differentially expressed NOS and arginase isoforms during neutrophil maturation (Kumar et al. 2010).

The capacity of ROS release and pathogen phagocysis is also important in innate immune response. ROS release is reduced in macrophages under the effects of simulated microgravity because of significantly reduced spleen tyrosine kinase Syk) phosphorylation (Adrian et al. 2013; Brungs et al. 2015). The oxidative burst of the neutrophils is increased immediately upon landing after a 5-11 day spaceflight mission compared to 10 days before launch (Kaur et al. 2004), but the spontaneous $\mathrm{H}_{2} \mathrm{O}_{2}$ production by PMNs after 30 subsequent parabolas remains unchanged. The phagocytic capacity of PMNs does not reveal significant changes after 5 day spaceflight mission or 30 subsequent parabolas, but increased after 9-, 10-, and 11-day spaceflight missions. We have not observed ROS release or phagocytic capacity alteration under the effects of simulated microgravity in this work (Fig. 4b-c), probably because the loading time $(72 \mathrm{~h})$ is not sufficiently long to lead significantly effects in HL-60 cells.

Varied profiles of cytokine secretion have been seen previously in spaceflight mission and by the effects of simulated microgravity. Specifically, cytokine production of monocytes, macrophages and endothelial cells is mostly reduced under microgravity, and distinct cytokines secreted by $\mathrm{T}$ lymphocytes respond differently to microgravity environment. Our study reveal the up-regulation of IL- $1 \beta$, IL-8, and MCP-1 in intact HL-60 cells and the enhanced secretion of IL-6, IL-8, and MCP-1 in PMN-like HL-60 cells under the effects of simulated microgravity. These cytokines are potent chemotactic and activating factors of PMN, monocytes, macrophages and lymphocytes, and responsible for fever and acute inflammatory response. The increased levels of these cytokines could lead to the activation of immune cells and the up-regulation of inflammatory immune responses. It should also be noticed that IL-8 could regulate the expression and activation of LFA-1 and Mac-1 (Li et al. 2013), therefore presenting the influence on adhesion molecules expression (Fig. 6a-b) and HL-60-endothelial interaction (Fig. 7).

LFA-1 and Mac-1 are two $\beta_{2}$ integrins expressed on PMNs, which mediate PMN recruitment cascade by binding to intercellular adhesion molecule (ICAM-1) (Ley et al. 2007). Here we observe the increased LFA-1 and Mac-1 expressions on intact and PMN-like HL-60 cells under the effects of simulated microgravity respectively (Fig. 6a-b), 
which could be responsible for the slightly enhanced adhesion (Fig. 7b) and reduced rolling velocity (Fig. 7a). We also notice the modest decreased PSGL-1 (Fig. 6d), which might result in disturbing selectin-PSGL-1 interaction (Jia et al. 2009; Xiao et al. 2012) and integrin activation (Yago et al. 2010), and then causing reduced adhesion (Fig. 7c). The static adhesion of PMNs to endothelial cells is enhanced before and after spaceflight in previous study (Stowe et al. 1999), but the PMN recruitment occurs in blood flow and is regulated by shear stress, suggesting that the flow chamber assay could reveal more physiological information than static adhesion assay.

Taken together, this work presents the effects of simulated microgravity on intact and PMN-like HL-60 cells for the first time, and the outcomes could well supplement those, very limited studies on PMN functions from spaceflights. Unlike other leukocytes, PMN-like cells respond to microgravity with the enhanced immune responses to some extent. They exhibit slightly enhanced NO production and up-regulation of IL-6, IL-8, and MCP-1. These data is in consistence with the increased PMN amount and cytokine secretion found in spaceflight (Stowe et al. 1999; Kaur et al. 2004). The reduced rolling velocity and decreased adhesion of PMN-like cells on endothelial cells under shear flow point out PMN recruitment might not be effective under microgravity, especially when the adhesion molecules on endothelial cells are decreased (Grenon et al. 2013). This work also implies that the effects of microgravity environment could be stimulated, at least partially, using a ground-based methodology with much low cost to predict how immune cells respond to the altered gravity. Physical principles, numerical simulations, human physiological tests, and spaceflight missions (Sun et al. 2008; Long et al. 2009; Feuerecker et al. 2013; Long 2014) are required to validate such ground-based predictions in the future works. Our findings furthers the understandings in the effects and mechanism of microgravity on PMN functions, which are potentially helpful for optimizing the countermeasures to immune suppression in the future long-term, manned spaceflight.

Acknowledgments This work was supported by National Key Basic Research Foundation of China grant 2011CB710904, National Natural Science Foundation of China grant 31110103918, Strategic Priority Research Program of Chinese Academy of Sciences grant XDA01030102, and National High Technology Research and Development Program of China grant 2011AA020109.

\section{References}

Adrian, A., Schoppmann, K., Sromicki, J., Brungs, S., von der Wiesche, M., Hock, B., Kolanus, W., Hemmersbach, R., Ullrich,
O.: The oxidative burst reaction in mammalian cells depends on gravity. Cell Commun. Signal 11, 98 (2013)

Armstrong, J.W., Gerren, R.A., Chapes, S.K.: The effect of space and parabolic flight on macrophage hematopoiesis and function. Exp. Cell Res 216(1), 160-168 (1995)

Bai, S.S., Li, Y., Wang, J.H., Zhai, D.X., Kong, Q.F., Liu, Y.M., Liu, X.J., Sun, B., Xu, J.Y., Wang, D.D., Wang, G.Y., Mu, L.L., $\mathrm{Xu}, \mathrm{X}$. Y., Li, H.L.: Modeled microgravity suppressed expansion of the MBP-specific T lymphocytes of rats with experimental autoimmune encephalomyelitis. Immunol. Invest 40(5), 535-551 (2011)

Baker, T.L., Goodwin, T.J.: Three dimensional culture of bovine chondrocytes in rotating-wall vessels. In virtro Cell Dev. Biol. Anim 33, 352-7 (1997)

Brungs, S., Kolanus, W., Hemmersbach, R.: Syk phosphorylation - a gravisensitive step in macrophage signaling. Cell Commun. Signal 13, 9 (2015)

Carrigan, S.O., Weppler, A.L., Isseutz, A.C., Stadnyk, A.W.: Neutrophil differentiated HL-60 cells model Mac-1(CD11b/CD18)independent neutrophil transepithelial migration. J. Immunol. 115(1), 108-117 (2005)

Chen, X., Yao, H.D., Yao, L.L., Zhao, J.X., Luan, Y.L., Zhang, Z.W., $\mathrm{Xu}, \mathrm{S} . \mathrm{W}$.: Selenium deficiency influences the gene expressions of heat shock proteins and nitric oxide levels in neutrophils of broilers. Biol. Trace. Elem. Res. 161(3), 334-340 (2014)

Cogoli, A., Tschopp, A.: Lymphocyte-reactivity during spaceflight. Immunol. Today 6(1), 1-4 (1985)

Collins, S.J., Gallo, R.C., Gallagher, R.E.: Continuous growth and differentiation of human myeloid leukaemic cells in suspension culture. Nature 270(5635), 347-349 (1977)

Cooper, D., Pellis, N.R.: Suppressed PHA activation of T lymphocytes in simulated microgravity is restored by direct activation of protein kinase C. J. Leukocyte Biol 63(5), 550-562 (1998)

Crucian, B.E., Stowe, R.P., Pierson, D.L., Sams, C.F.: Immune system dysregulation following short- vs long-duration spaceflight. Aviat. Space Environ. Med 79(9), 835-843 (2008)

Crucian, B., Stowe, R., Quiriarte, H., Pierson, D., Sams, C.: Monocyte phenotype and cytokine production profiles are dysregulated by short-duration spaceflight. Aviat. Space Environ Med 82(9), 857$862(2011)$

Crucian, B., Stowe, R., Mehta, S., Uchakin, P., Quiriarte, H., Pierson, D., Sams, C.: Immune system dysregulation occurs during short duration spaceflight on board the space shuttle. J. Clin. Immunol 33(2), 456-465 (2013)

Feuerecker, M., Feuerecker, B., Matzel, S., Long, M., Strewe, C., Kaufmann, I., Hoerl, M., Schelling, G., Rehm, M., Choukèr, A.: Five days head down tilt bed rest induces noninflammatory shedding of L-selectin. J. Applied Physiol. 115, 235-242 (2013)

Goodwin, T.J., Schroeder, W.F., Wolf, D.A., Moyer, M.P.: RotatingWall Vessel Co-culture of small intestine as a prelude to tissue modeling: aspects of simulated microgravity. Proc. Soc. Exp. Biol. Med 202, 181-92 (1993)

Grenon, S.M., Jeanne, M., Aguado-Zuniga, J., Conte, M.S., HughesFulford, M.: Effects of gravitational mechanical unloading in endothelial cells: association between caveolins, inflammation and adhesion molecules. Sci. Rep. 3, 1494 (2013)

Gridley, D.S., Slater, J.M., Luo-Owen, X., Rizvi, A., Chapes, S.K., Stodieck, L.S., Ferguson, V.L., Pecaut, M.J.: Spaceflight effects on T lymphocyte distribution, function and gene expression. J. Appl. Physiol. 106(1), 194-202 (2013)

Griffoni, C., Di Molfetta, S., Fantozzi, L., Zanetti, C., Pippia, P., Tomasi, V., Spisni, E.: Modification of Proteins Secreted by Endothelial Cells During Modeled Low Gravity Exposure. J. Cell. Biochem. 112(1), 265-272 (2011) 
Hawkins, W.R., Zieglschmid, J.F.: SP-368 Biomedical results of Apollo, clinical aspects of crew health. Johnson Space Centre (1975)

Herranz, R., Anken, R., Boonstra, J., Braun, M., Christianen, P.C.M., de Geest, M., Hauslage, J., Hilbig, R., Hill, R.J.A., Lebert, M., Medina, F.J., Vagt, N., Ullrich, O., van Loon, J.J.W.A., Hemmersbach, R.: Ground-Based Facilities for Simulation of microgravity: organism-specific recommendations for their use, and recommended terminology. Astrobiology $\mathbf{1 3}$ (1), 1-17 (2013)

Hsieh, C.L., Chao, P.D.L., Fang, S.H.: Morin sulphates/glucuronides enhance macrophage functioning microgravity culture system. Eur. J. Clin. Invest 35(9), 591-596 (2005)

Jia, X.L., Chen, J., Long, M.: IL-8-induced L-selectin shedding regulates its binding kinetics to PSGL-1. Chin. Sci. Bull 54(16), 27862793 (2009)

Kaur, I., Simons, E.R., Castro, V.A., Mark Ott, C., Pierson, D.L.: Changes in neutrophil functions in astronauts. Brain Behav. Immun. 18(5), 443-450 (2004)

Kaur, I., Simons, E.R., Castro, V.A., Ott, C.M., Pierson, D.L.: Changes in monocytes functions of astronauts. Brain Behav. Immun. 19(6), 547-554 (2005)

Kaur, I., Simons, E.R., Kapadia, A.S., Ott, C.M., Pierson, D.L.: Effect of spaceflight on ability of monocytes to respond to endotoxins of gram-negative bacteria. Clin. Vaccine Immunol. 15(10), 15231528 (2008)

Kaufmann, I., Schachtner, T., Feuerecker, M., Schelling, G., Thiel, M., Chouker, A.: Parabolic flight primes cytotoxic capabilities of polymorphonuclear leucocytes in humans. Eur. J. Clin. Invest. 39(8), 723-728 (2009)

Kaufmann, I., Feuerecker, M., Salam, A., Schelling, G., Thiel, M., Chouker, A.: Adenosine A2(A) receptor modulates the oxidative stress response of primed polymorphonuclear leukocytes after parabolic flight. Hum. Immunol. 72(7), 547-552 (2011)

Konstantinova, I.V., Rykova, M.P., Lesnyak, A.T., Antropova, E.A.: Immune changes during long-duration missions. J. Leukoc. Biol. 54(3), 189-201 (1993)

Konstantinova, I.V., Rykova, M., Meshkov, D., Peres, C., Husson, D., Schmitt, D.A.: Natural killer cells after ALTAIR mission. Acta Astronaut 36(8-12), 713-718 (1995)

Kumar, S., Jyoti, A., Keshari, R.S., Singh, M., Barthwal, M.K., Dikshit, M.: Functional and molecular characterization of NOS isoforms in rat neutrophil precursor cells. Cytometry Part A. 77A, 467-477 (2010)

Lefort, C.T., Hyun, Y.M., Schultz, J.B., Law, F.Y., Waugh, R.E., Knauf, P.A., Kim, M.: Outside-in signal transmission by conformational changes in integrin Mac-1. J. Immonol. 183(10), 64606468 (2009)

Ley, K., Laudanna, C., Cybulsky, M.I., Nourshargh, S.: Getting to the site of inflammation: the leukocytes adhesion cascade updated. Nat. Rev. Immonol 7(9), 678-689 (2007)

Li, N., Mao, D.B., Lü, S.Q., Tong, C.F., Zhang, Y., Long, M.: Distinct binding affinities of Mac-1 and LFA-1 in neutrophil activation. J. Immunol 190(8), 4371-4381 (2013)

Long, M., Sun, S.J., Huo, B., Shu, N.J., Tao, Z.L., Gao, Y.X.: Biomechanics on cell responses to microgravity. In: Hu, W.R. (ed.) Advances in Microgravity Sciences, pp. 215-233. Transworld Research Network Press (2009)

Long, M.: How to stimulate a space microgravity environment or effect on Earth from the viewpoint of responses of space cell growth to microgravity. Chin. Sci. Bull. 59(20), 2004-2015 (2014)

Loos, T., Opdenakker, G., Van Damme, J., Proost, P.: Citrullination of CXCL8 increases this chemokine's ability to mobilize neutrophils into the blood circulation. Haematol-hematol. J 94(10), 1346-1353 (2009)
Martin, A., Zhou, A., Gordon, R.E., Henderson, S.C., Schwartz, A.E., Friedman, E.W., Davis, T.F.: Thyroid organoid formation in simulated microgravity: influence of keratinocyte growth factor. Thyroid 10, 481-7 (2000)

McGarry, J.G., Maguire, P., Campbell, V.A., O'Connell, B.C., Prendergast, P.J., Jarvis, S.P.: Stimulation of nitric oxide mechanotransduction in single osteoblasts using atomic force microscopy. J. Orthop. Res. 26(4), 513-521 (2008)

Mehta, S.K., Kaur, I., Grimm, E.A., Smid, C., Feeback, D.L., Pierson, D.L.: Decreased non-MHC-restricted $(\mathrm{CD} 56(+))$ killer cell cytotoxicity after spaceflight. J. Appl. Physiol. 91(4), 1814-1818 (2001)

Meshkov, D., Rykova, M.: The natural cytotoxicity in cosmonauts on board space stations. Acta Astronaut. 36(8-12), 719-726 (1995)

Mills, P.J., Perez, C.J., Adler, K.A., Ziegler, M.G.: The effects of spaceflight on adrenergic receptors and agonists and cell adhesion molecule expression. J. Neuroimmunol. 132(1-2), 173-179 (2002)

Miura, Y., Tohyama, Y., Hishita, T., Lala, A., Nardin, E.D., Yamamura, Y.H., Uchiyama, T., Tohyama, K.: Pyk2 and Syk participate in functional activation of granulocytic HL-60 cells in a different manner. Blood 96(5), 1733-1739 (2000)

Newburger, P.E., Chovaniec, M.E., Greenberger, J.S., Cohen, H.J.: Functional changes in human leukemic cell line HL-60: A model for myeloid differentiation. J. Cell Biology 82(2), 315-322 (1979)

Ortega, M.T., Pecaut, M.J., Gridley, D.S., Stodieck, L.S., Ferguson, V., Chapes, S.K.: Shifts in bone marrow cell phenotypes caused by spaceflight. J. Appl. Physiol. 106(2), 548-555 (2009)

Ortega, M.T., Lu, N.Y., Chapes, S.K.: Evaluation of in vitro macrophage differentiation during space flight. Adv. Space Res. 49(10), 1441-1455 (2012)

Paulsen, K., Tauber, S., Dumrese, C., Bradacs, G., Simmet, D.M., Goelz, N., Hauschild, S., Raig, C., Engeli, S., Gutewort, A., Huerlimann, E., Biskup, J., Unverdorben, F., Rieder, G., Hofmaenner, D., Mutschler, L., Krammer, S., Buttron, I., Philpot, C., Huge, A., Lier, H., Barz, I., Engelmann, F., Layer, L.E., Thiel, C.S., Ullrich, O.: Regulation of ICAM-1 in cells of the monocyte/macrophage system in microgravity, vol. 2015, p. 538786 (2015)

Pavanelli, W.R., Gutierrez, F.R.S., daSilva, J.J.N., Costa, I.C., de Menezes, M.C.N.D., Oliveira, F.J.D., Itano, E.N., Watanabe, M.A.E.: The effects of nitric oxide on the immune response during giardiasis. J. Infect. Dis. 14(6), 606-612 (2010)

Rizzo, V., McIntosh, D.P., Oh, P., Schnitzer, J.E.: In situ flow activates endothelial nitric oxide synthase in luminal caveolae of endothelium with rapid caveolin dissociation and calmodulin association. J. Biol. Chem. 273(52), 34724-34729 (1998)

Rykova, M.P., Sonnenfeld, G., Lesnyak, A.T., Taylor, G.R., Meshkov, D.O., Mandel, A.D., Medvedev, A.E., Berry, W.D., Fuchs, B.B., Konstantinova, I.V.: Effect of spaceflight on natural-killer-cell activity. J. Appl. Physiol. 73(2), S196-S200 (1992)

Savary, C.A., Grazziutti, M.L., Przepiorka, D., Tomasovic, S.P., McIntyre, B.W., Woodside, D.G., Pellis, N.R., Pierson, D.L., Rex, J.H.: Characteristics of human dendritic cells generated in a microgravity analog culture system. In Vitro Cell. Dev. Biol. -Animal 37(4), 216-222 (2001)

Sawyer, D.W., Donowitz, G.R., Mandell, G.L.: Polymorphonuclear neutrophils: An effective antimicrobial force. Rev. Infect. Dis. 11, S1532-S1544 (1989)

Shatanawi, A., Lemtalsi, T., Yao, L., Patel, C., Caldwell, R.B., Caldwell, R.W.: Angiotensin II limits NO production by upregulating arginase through a p38 MAPK-ATF-2 pathway. Eur. J. Pharmacol. 746, 106-114 (2015)

Singh, K.P., Kumari, R., DuMond, J.W.: Simulated microgravityinduced epigenetic changes in human lymphocytes. J. Cell Biochem. 111(1), 123-129 (2010) 
Stowe, R.P., Sams, C.F., Mehta, S.K., Kaur, I., Jones, M.L., Feeback, D.L., Pierson, D.L.: Leukocyte subsets and neutrophil function after short-term spaceflight. J. Leukoc. Biol. 65(2), 179-186 (1999)

Sun, S.J., Gao, Y.X., Shu, N.J., Tao, Z.L., Long, M.: A novel counter sheet-flow sandwich cell culture system to unravel cellular responses in space. Microgravity Sci. Tech. 20(2), 115-120 (2008)

Tsiftsoglou, A.S., Pappas, I.S., Vizirianakis, I.S.: Mechanisms involved in the induced differentiation of leukemia cells. Pharmacol. Therapeut 100(3), 257-290 (2003)

Ulbrich, C., Westphal, K., Baatout, S., Wehland, M., Bauer, J., Flick, B., Infanger, M., Kreutz, R., Vadrucci, S., Egli, M., Cogoli, A., Derradji, H., Pietsch, J., Paul, M., Grimm, D.: Effects of basic fibroblast growth factor on endothelial cells under conditions of simulated microgravity. J. Cell. Biochem. 104(4), 1324-1341 (2008)

Van Eeden, S.F., Terashima, T.: Interleukin 8 (IL-8) and the release of leukocytes from the bone marrow, vol. 37, pp. 259-+ (2000)

Varani, J., Ward, P.A.: Mechanisms of endothelial cell injury in acute inflammation. Shock 2(5), 311-319 (1994)

Versari, S., Villa, A., Bradamante, S., Maier, J.A.M.: Alterations of the actin cytoskeleton and increased nitric oxide synthesis are common features in human primary endothelial cell response to changes in gravity. BBA-Mol Cell Res. 1773(11), 1645-1652 (2007)

Vorselen, D., Roos, W.H., MacKintosh, F.C., Wuite, G.J.L., van Loon, J.J.W.A.: The role of the cytoskeleton in sensing changes in gravity by nonspecialized cells. Faseb. J. 28 (2), 536-547 (2014)

Wang, C.Z., Luo, H.Y., Zhu, L.N., Yang, F., Chu, Z.L., Tian, H.L., Feng, M.F., Zhao, Y., Shang, P.: Microgravity inhibition of lipopolysaccharide-induced tumor necrosis factor- $\alpha$ expression in macrophage cells. Inflamm. Res. 63(1), 91-98 (2014)
Wang, C.Z., Chen, H., Luo, H.Y., Zhu, L.N., Zhao, Y., Tian, H.L., Wang, R.Y., Shang, P., Zhao, Y.: Microgravity activates p38 MAPK-C/EBP $\beta$ pathway to regulate the expression of arginase and inflammatory cytokines in macrophages. Inflamm. Res. 64(5), 303-311 (2015)

Warnke, E., Kopp, S., Wehland, M., Hemmersbach, R., Bauer, J., Pietsch, J., Infanger, M., Grimm, D.: Thyroid Cells Exposed to Simulated Microgravity Conditions Comparison of the Fast Rotating Clinostat and the Random Positioning Machine. Microgravity Sci. Technol., $1-14(2015)$

Xiao, B.T., Tong, C.F., Jia, X.L., Guo, R., Lü, S.Q., Zhang, Y., McEver, R.P., Zhu, C., Long, M.: Tyrosine replacement of PSGL-1 reduces association kinetics with P- and L-selectin on the cell membrane. Biophys. J 103(4), 777-785 (2012)

Yago, T., Shao, B., Miner, J.J., Yao, L.B., Klopocki, A.G., Maeda, K., Coggeshall, K.M., McEver, R.P.: E-selectin engages PSGL-1 and CD44 through a common signaling pathway to induce integrin $\alpha_{\mathrm{L}} \beta_{2}$-mediated slow leukocyte rolling. Blood 116(3), 485$494(2010)$

Yi, Z.C., Xia, B., Xue, M., Zhang, G.Y., Wang, H., Zhou, H.M., Sun, Y., Zhuang, F.Y.: Simulated microgravity inhibits the proliferation of K562 erythroleukemia cells but does not result in apoptosis. Adv. Space Res. 44 (2), 233-244 (2009)

Zemans, R.L., Arndt, P.G.: Tec kinases regulate actin assembly and cytokine expression in LPS-stimulated human neutrophils via JNK activation. Cell Immunol. 258(1), 9097 (2009)

Zhang, Y., Sang, C., Katrin, P., Andrea, A., Zhao, Z.Y., Jia, X.L., Oliver, U., Zhuang, F.Y.: ICAM-1 expression and organization in human endothelial cells is sensitive to gravity. Acta Astronautica 67(9-10), 1073-1080 (2010) 